\title{
ЗАНЯТИЕ АДВОКАТОМ НЕПРОФИЛИРУЮЩИМИ ВИДАМИ ДЕЯТЕЛЬНОСТИ
}

\begin{abstract}
Аннотация: В статье устанавливается перечень некоторых видов деятельности, занятие которыми или запрещено, или ограничено в отношении лища, обладающего статусом российского адвоката. Автор выделяет принципы, которые привели к появлению подобных ограничений.

Ключевые слова: Юриспруденция, адвокат, бизнес-адвокат, статус, коммериия, независимость, номинальный, работник, семибоярщина, роман
\end{abstract}

B опрос о том, имеет ли право адвокат заниматься иной, кроме адвокатской, деятельностью, давно уже является как предметом доктринальных дискуссий, так и источником некоторой неопределенности самого законодателя. Дело в том, что лица, получившие некий юридический статус, согласно концепции равенства прав и обязанностей, приобретают в связи с этим не только права и преференции, но и ограничения. Наиболее ярко это проявляется, например, при получении лицом статуса государственного служащего. Кроме жалования и различных льгот последний приобретает и определенные обременения, причем не только для себя, но порой и для членов своей семьи: обязательная подача налоговой декларации, ограничение стоимости получаемых подарков, запрет заниматься коммерческой деятельностью и т.п. Однако подобные ограничения, связанные с приобретением определенного статуса, действуют не только в публичной, но и в частной сфере. Так, законодатель ограничивает свободу деятельности лиц, обладающих особым негосударственным (частным) статусом. Этот переход правил публичных отношений на частные особенно рельефно проявляется в институте поверенного права. Рассмотрим некоторые из этих ограничений.

Право заниматься коммерческой деятельноcтью. Еще в период обсуждения различных проектов Федерального закона от 3 мая 2002 г. N 63-Ф3 «Об адвокатской деятельности и адвокатуре в Российской Федерации» (далее - Закон об адвокатуре) предметом жарких споров стал вопрос, могут ли адвокаты заниматься коммерческой деятельностью? Одни авторы выступали за допустимость коммерческого элемента в адвокатскую деятельность, другие заявляли, что коммерция претит самой сути этой профессии ${ }^{1}$.

Первоначальная редакция Закона об адвокатуре дала на этот вопрос однозначный ответ: «Адвокат не вправе заниматься другой оплачиваемой деятельностью, за исключением научной, преподавательской и иной творческой деятельности». В дальнейшем оказалось, что в правоприменительной практике эта норма большого значения не имела. Адвокаты «потихому» занимались коммерцией, так как доказать, а значит, и наказать за это, практически невозможно. Изменения, внесенные в Закон об адвокатуре от 20 декабря 2004 г., ликвидировали этот запрет. Норма о том, что адвокат не имеет права заниматься иной, кроме адвокатской, оплачиваемой деятельностью была изъята из текста закона ${ }^{2}$. Но даже после подобного изменения в законодательстве, точка в этом вопросе поставлена не была. Так, налоговые органы, ссылаясь на статью 9 Кодекса профессиональной этики адвоката (принят первым Всероссийским съездом адвокатов 31 января 2003 г.), запрещающую адвокату: «заниматься иной оплачиваемой деятельностью в форме непосредственного (личного) участия в процессе реализации товаров, выполнения работ или

\footnotetext{
${ }^{1}$ См.: Буробин В. Н. Коммерциализация адвокатуры - благо для ее развития // Российская юстиция. N 5. 2002., Резник. Г. В адвокатуре завелся вирус коммерции, но эпидемия предотвратима // Российская юстиция. N 11. 1999.

${ }^{2}$ См.: Мельниченко Р. Г. Поправки к Закону об адвокатуре: работа над ошибками // Адвокат. № 5. 2005. С. 46-48.
} 
DOI: 10.7256/1811-9018.2013.7.988

При цитировании этой статьи сноска на doi обязательна

\section{Право и политика 7 (163) 2013}

оказания услуг», считают, что адвокат не имеет права заниматься коммерческой деятельностью. Так, в деле «Налоговая служба против адвоката К.», государственные органы посчитали, что статус адвоката не позволяет последнему выступать в качестве учредителя коммерческого юридического лица ${ }^{3}$. Квалификационная комиссия, рассмотрев указанное дело, отметила, что в законодательстве отсутствует запрет адвокату выступать в качестве учредителя хозяйствующих обществ и товариществ.

Ситуация, сложившееся в ходе обсуждения вопроса, имеет ли право адвокат заниматься иной оплачиваемой деятельностью, является показательной. До сегодняшнего дня нет единого понимания того, позволительно ли вообще адвокату заниматься иной деятельностью, не обязательно оплачиваемой. Некоторые авторы одним из признаков адвокатской деятельности указывают ее «исключительность», т.е. запрет адвоката на занятие иной оплачиваемой деятельностью ${ }^{4}$.

Установим несколько принципов, основываясь на которые, можно определить, имеет ли право, а если имеет, то при каких условиях, адвокат заниматься непрофильной деятельностью.

Основным приничипом, служащим критерием допуска адвоката к занятию непрофильной деятельностью, является требование того, что в ходе ее осуществления адвокат не должен ставить под угрозу свою независимость.

Второй принциип следует из требований статьи 9 Кодекса профессиональной этики адвоката, согласно которой «выполнение профессиональных обязанностей по принятым поручениям должно иметь для адвоката приоритетное значение над иной деятельностью». Этот принцип обязывает адвоката осуществлять свою возможную не адвокатскую деятельность таким образом, чтобы она не препятствовала ему выполнять адвокатские обязанности. Например, если адвокат осуществляет преподавательскую деятельность, то вопрос, пойти на лекцию или на назначенное на это время судебное заседание, должен быть разрешен однозначно - на судебное заседание.

Третий принциип заключается в том, что осуществляемая адвокатом его параллельная не адвокатская деятельность не должна порочить честь и достоинство адвоката или наносить ущерб авторитету адвокатуры. Например, участие адвоката в работе

\footnotetext{
${ }^{3}$ Обзор дисциплинарной практики Совета Адвокатской палаты г. Москвы // Адвокат. № 6.2008. С-20-22.

${ }^{4}$ Кучерена А.Г. Адвокатура: Учебник. - М., 2004. С. 46.
}

коллекторного агентства в качестве учредителя является несовместимым со статусом адвоката.

И четвертый принциип связан с таким понятием, как «номинальный адвокат». Под номинальным адвокатом понимается лицо, обладающее статусом адвоката, но фактически не занимающимся адвокатской деятельностью. Эти адвокаты, не занимаясь адвокатским трудом, могут утерять психологическую и профессиональную связь со своей профессией.

Исходя из выделенных принципов, можно исследовать различные виды не адвокатской деятельности на предмет того, имеет ли право адвокат ими заниматься.

Адвокат-работник. Согласно действующей редакции Закон об адвокатуре устанавливает требование, согласно которому: «адвокат не вправе вступать в трудовые отношения в качестве работника...». Работник является зависимым от работодателя лицом. Основной же принцип адвокатской деятельности - независимость адвокатуры - не позволяет адвокатам быть зависимыми наемными работниками. Указанное требование проявляется, например, при оформлении отношений между адвокатом и клиентом-юридическим лицом. Эти отношения оформляются не трудовым, а гражданско-правовым договором на юридическое обслуживание. Из запрета на занятие адвокатом трудовой деятельностью существуют два исключения. Первое - адвокат имеет право выступать в качестве работника при занятии научной, преподавательской и иной творческой деятельностью. Второе - адвокат может занять руководящую должность в адвокатской фирме или органе адвокатского самоуправления. Разберем эти исключения более подробно.

Разрешение на занятие творческой деятельностью преследует своей целью побудить адвокатов заниматься повышением своей квалификации. Ведь и научная, и преподавательская деятельность стимулирует адвоката, ею занимающегося, пополнять свои знания в области юриспруденции. Кроме того, присутствие в адвокатских кругах ученых и преподавателей повышает престиж всего адвокатского сообщества. Угроза же утраты независимости адвоката-ученого - минимальна. По сути своей профессии ученые и преподаватели тяготеют к независимости и даже некому бунтарству. Единственно, как уже было изложено выше, для адвоката его творческая деятельность не должна превалировать над его основным видом деятельности. Кроме того, в этой связи хотелось бы затронуть не совсем приятный для самого автора вопрос о возможности занятия адвокатом административных должностей в области науки и образования. Ни для кого не секрет, что ряд 
адвокатов, включая автора статьи, занимают административные руководящие должности в учебных заведениях: заведующие кафедрами, проректоры и даже ректоры ведущих вузов России. С юридической позиции, эти должности являются полуадминистративными - полупреподавательскими. Ведь, как правило, в служебные обязанности заведующего кафедрой входит и педагогическая нагрузка. Угроза потери независимости этим адвокатам не грозит. Однако эти адвокаты склонны к переходу в категорию номинальных адвокатов. Ведь указанные должности требуют значительных временных затрат, не позволяющих порой вести даже вялотекущую адвокатскую деятельность.

Участие адвоката в работе органов адвокатского самоуправления так же является исключением в запрете для занятия адвокатом трудом в качестве работника. Закон об адвокатуре устанавливает за адвокатом право совмещать свою адвокатскую деятельность на выборных должностях адвокатской палаты субъекта Российской Федерации и Федеральной палаты адвокатов.

Закон об адвокатуре содержит в себе защитный механизм, препятствующий захвату власти в адвокатском сообществе одними и теми же лицами. Так, срок полномочий президента адвокатской палаты не может быть более восьми лет. Для представителей совета адвокатской палаты Закон об адвокатуре устанавливает ротацию (обновление) совета один раз в два года на одну треть. Но в практике работы советов установилось правило, что две трети состава совета не изменяются (постоянные члены), а одна треть временная (одноразовая) и подлежит замене каждые два года. О наличии такого положения может убедиться каждый адвокат. Во многом это происходит из-за неверного толкования постоянными членами советов адвокатских палат термина «ротация». Согласно словарю по общественным наукам Глоссарий.ру, термин «Ротация» произошел от латинского Rotatio - круговращение. «Ротация - постоянное обновление состава представительных органов и их функций с целью предотвращения их бюрократизации». При помощи ротации достигаются две цели: обеспечить смену всех управленцев и, при этом, обеспечить стабильность и преемственность в работе представительного органа. Согласно Современному экономическому словарю под редакцией Райзберг Б.А., Лозовс кий Л.Ш., Стародубцева Е.Б.: «Ротация - поочередная замена руководителей с целью обновления управленческого аппарата и создания возможностей роста, повышения в должности». Обращаем внимание на используемое словосочетание «поочередная замена». Сегодня в России начинает образовываться новый вид адвокатов, получивший в средствах массовой информации наименование «генералы от адвокатуры» (по нашему мнению, здесь будет уместнее термин «бояре от адвокатуры», а само явление - «адвокатская семибоярщина»), которые бессменно стоят у руля адвокатской корпорации. Подобная тактика «обояривания» получает свое распространение и в других органах, связанных с адвокатурой. Например, члены квалификационной комиссии от адвокатского сообщества, как правило, переизбираются и могут занимать свой пост неограниченное время - комиссия остается в одном и том же составе.

Сложившееся положение противоречит не только принципам организации адвокатуры, но и выделенным принципам по ограничению занятия адвокатом непрофильным видом деятельности. В этой связи мы хотели бы предложить, в рамках уже существующей модели организации органов адвокатского самоуправления, некоторые поправки, позволяющие выровнять возникшую конфликтную ситуацию.

Во-первых, в связи с неверным толкованием термина «ротация», появилась необходимость внесения в ч. 2 ст. 31 Закона об адвокатуре дополнения следующего содержания: «При этом одно и то же лицо не может занимать должность члена совета адвокатской палаты более шести лет подряд». Адвокатская элита в ближайшее время должна кардинально обновиться. К слову, попытка внесения подобной поправки в Устав Адвокатской палаты Волгоградской области была заблокирована Советом адвокатской палаты.

Во-вторых, место в совете адвокатской палаты является почетным правом. Адвокат, занявший это место, априори является одним из лучших адвокатов, а его место в совете сигнализирует об этом всем окружающим, в том числе и потенциальным клиентам. Именно поэтому оплата его работы в совете адвокатской палаты (своеобразное кормление) является не только излишней, но даже вредной. Адвокат должен работать в совете из-за своих внутренних убеждений, а не в расчете на денежное вознаграждение. Впрочем, это предложение не относится к президентам адвокатских палат, которые, в связи со своей служебной занятостью, практически лишаются доходов от своей адвокатской деятельности.

Завершая вопрос о возможности адвокатом занимать руководящие должности в органах адвокатского самоуправления, хотелось бы указать на огромную опасность, возникающую в этой связи для адвокатов-управленцев. Значительные временные затраты на осуществление своих административных обязанностей, так же как и в случае с адвокатом-ученым, создают угрозу для перехода этого адвоката в категорию номинальных адвокатов. 
DOI: 10.7256/1811-9018.2013.7.988

При цитировании этой статьи сноска на doi обязательна

\section{Право и политика 7 (163) • 2013}

Занятие адвокатом бизнес-юриспруденичей является следующей ситуацией, нуждающийся в доктринальном анализе. О наличии такой категории как смежные адвокатские услуги можно говорить, опираясь на п. 3 ст. 2 Закона об адвокатуре. Согласно этому пункту, адвокат вправе оказывать иную юридическую помощь, не запрещенную федеральным законом. То есть список адвокатских услуг является открытым. Необходимо доктринально определить его содержание, т.е. определить сферу смежных адвокатских услуг.

Ряд авторов, в большинстве своем практикующих адвокатов, уже нащупали наличие данного вида адвокатских услуг и подвели под нее научную базу. В своих работах эту сферу адвокатских услуг авторы назвали бизнес адвокатурой или «Правовым обслуживанием адвокатом сферы хозяйственных отношений и защиты предпринимательства» ${ }^{5}$.

Такой вид адвокатской деятельности как бизнесадвокатура становится в последнее время все более популярной. Эта деятельность связана с оказанием адвокатами квалифицированной юридической помощи хозяйствующим субъектам: коммерческим юридическим лицам и индивидуальным предпринимателям. Эта деятельность может заключаться в нескольких аспектах: юридическая консультация руководства предприятия и правовой анализ их юридических документов, ведения дел предприятий в арбитражных судах и судах общей юрисдикции, участие в подборе кадров на должность юрисконсульта (кастинг) и т.п. Данный вид адвокатских услуг довольно востребован на современном российском рынке. Об этом говорит и процветание известных российских адвокатских фирм, специализирующихся в этой сфере. Однако стоит заметить, что суть адвокатской профессии заключается в работе с «простыми» людьми. Людьми, перед которыми возникли персональные юридические проблемы. Адвокат же, работая с крупными корпоративными клиентами, может утерять не только навык общения с классическим клиентом, но и подвергается риску утраты своего основного профессионального качества - независимости. Адвокат-юрисконсульт - это слуга двух господ, своей адвокатской этики и своего состоятельного, подчас одного, корпоративного хозяина. Неслучайно некоторые государства ограничивают эту сферу адвокатских услуг. Так, согласно законам Нидерландов, адвокаты, являющиеся членами Нидерландской Ассоциации

5 Смоленский М.Б. Адвокатская деятельность и адвокатура Российской Федерации: Учебник. Ростов н/Д., 2003. C. 185-198.
Адвокатов, не вправе предоставлять юридические услуги в сферах бизнеса и управления. Думается, что и в России занятие адвокатом бизнес-адвокатурой должно быть ограничено.

Следующим ограничением, накладываемым на адвоката, является табу на его участие в политической деятельности. Мировая история знает множество примеров появления известных политиков именно из адвокатской среды: Робеспьер, Керенский, Ульянов и т.п. Активность, развитые риторские способности, целеустремленность - все эти качества позволяют адвокатам успешно заниматься политической деятельностью и добиваться в ней значительных результатов. Сегодня многие бывшие российские адвокаты активно занимаются политикой, занимая те или иные руководящие посты, как на федеральном уровне, так и на уровне субъектов Российской Федерации. Введение ограничений на занятие адвокатами политикой обусловлено некоторыми причинами.

Во-первых, занятие адвоката политикой может привести последнего к необходимости осуществлять критику существующего политического режима. В этой связи еще Наполеон І говорил: «До тех пор, пока я буду носить шпагу, я не позволю адвокатам говорить против правительства» ${ }^{6}$. Этот запрет был закреплен в некоторых корпоративных актах адвокатских сообществ. Так, согласно правилам адвокатской профессии во Франции: «Нечего напоминать адвокатам, что они нарушают присягу, когда в речах или письменных объяснениях нападают на общественную или религиозную нравственность, на государственные основы, законы и предержащую власть»7.

Во-вторых, классическая адвокатура всегда воспринималась населением в качестве некого аппозиционного органа. Адвокат, по роду своей деятельности противопоставлен милиции, прокуратуре, суду, т.е. всем органам государственной власти. И потому любые заявления, сделанные от имени адвокатского сообщества в поддержку правящей власти (при этом неважно, хорошая эта власть или плохая), постепенно разрушают в общественном сознании образ независимого адвоката.

Наличие у лица статуса российского адвоката не исключает его права заниматься политической деятельностью. Однако особый юридический статус

${ }^{6}$ Лохвицкий А.В. Французская адвокатура Профессия адвоката: Сборник работ о французской адвокатуре / Сост. А.В. Поляков. - M., 2006. C. 44.

${ }^{7}$ Молло Ф. Правила адвокатской профессии во Франции. M., 1894. 
налагает на адвоката в этой сфере определенные ограничения. Наличие этого тезиса можно проследить в современном российском поверенном законодательстве. Так, Закон об адвокатуре содержит такое основание приостановления статуса адвоката, как избрание адвоката в орган государственной власти или орган местного самоуправления на период работы на постоянной основе. То есть, статус официального политика и статус адвоката несовместимы. Однако некоторые адвокаты стремятся найти, а затем втиснуться в «щель» между статусом адвоката и статусом политика. Какие щели они находят, и к каким последствиям это может привести, мы попытаемся продемонстрировать на конкретных примерах.

Хорошим рекламным ходом считается личное выдвижение кандидатуры адвоката на каких-нибудь выборах. Даже если результат в итоге будет отрицательным, все равно, предвыборная кампания - это время беспроигрышного раскручивания своего имени. К примеру, адвокатесса К. в ходе предвыборной кампании применила следующий рекламный ход. Ее представители, совершая обход квартир граждан, просили их подписать исковое заявление к властям города. Кандидат в депутаты К. в качестве адвокатессы обещала впоследствии обратиться с этим заявлением в суд. Люди, видя бескорыстное внимание к своим проблемам кандидата-адвоката, «делали свой выбор». Конечно же, после выборов никаких действий со стороны адвокатессы не последовало. Если бы этот рекламный ход применил другой кандидат, это было бы приемлемо с позиции общественной и политической морали. Совсем другая ситуация, когда его применяет адвокат. После подобного случая, у его обманутых избирателей может сложиться неприязненное отношение ко всем адвокатам.

Второй пример иллюстрирует ситуацию еще более опасную для адвокатского сообщества. Адвокатура как институт гражданского общества имеет свои задачи, отделена от государства и не должна от своего имени участвовать в политической деятельности. Ряд адвокатов-управленцев, состоящих в той или иной партии, используют свой статус членов советов адвокатских палат для втягивания адвокатуры в политическую деятельность на стороне «своей» партии. Это проявляется по-разному: от прямой агитации за определенного кандидата или партию на общем собрании (конференции) адвокатской палаты, предоставления в корпоративных СМИ места для предвыборной агитации «нужного» кандидата, до прямых публичных предвыборных призывов некоторых руководителей, из чего у рядового обывателя может сложиться мнение, что все адвокаты, голосуют за....
Все приведенные политические деяния адвокатов входят в противоречие с принципом, запрещающим при занятии адвокатом непрофильным видом деятельности умалять авторитет адвокатуры.

Для предотвращения втягивания адвокатской корпорации в политическую деятельность в Кодекс профессиональной этики адвоката, необходимо внести норму, относящуюся ко всем адвокатам, следующего содержания: «В случае участия адвоката в какой-либо форме в избирательной кампании, ему запрещено упоминать в агитационных материалах о своей принадлежности к адвокатской профессии». Более жесткое правило необходимо установить по отношению к руководителям органов адвокатского самоуправления (президентам и членам советов адвокатских палат): «Руководителю органа адвокатского самоуправления запрещается участвовать в предвыборной агитации за кандидатов или политическую партию, используя свой образ, комментарии, высказывания и т.п.».

Еще одним ограничением, налагаемым на адвоката сутью его профессии, можно назвать бурно развивающееся в определенной адвокатской среде поветрие - адвокатское графоманство. Мы не будем говорить о литературном качестве так называемых «адвокатских романов», это, во-первых, находится вне нашей компетенции, а, во-вторых, на каждую книгу найдется свой читатель. Ведь стал же, в конце концов, адвокат Жюль Верн писателем с мировым именем. Нас интересует этический аспект, возникающий в ходе публикации подобной художественной литературы.

Для примера, возьмем творчество самого известного современного писателя адвокатских романов - Павла Астахова. На первый взгляд, у каждого адвоката, ознакомившегося с каким-либо произведением этого адвоката-писателя, возникнет чувство благодарности к этому популяризатору адвокатской профессии в России. В каждом произведении в сознание читателя внедряется образ адвоката-героя и, соответственно, негативные образы врагов любого адвоката. По сути, Павел Астахов в одиночку выполняет функции, которые должны осуществлять Федеральная палата Адвокатов РФ и адвокатские палаты субъектов РФ вместе взятые, которые заключаются в работе над популяризацией как адвокатской корпорации в целом, так и образа конкретного адвоката в частности. Другое дело можно ли, используя метод хороший-плохой, добиться этой цели - вопрос уже к профессиональным имиджмейкерам. О чем мы можем заявить твердо, это то, что адвокат Павел Астахов своими произведениями нарушает правила корпоративной этики 
DOI: 10.7256/1811-9018.2013.7.988

При цитировании этой статьи сноска на doi обязательна

\section{Право и политика 7 (163) 2013}

адвокатов. Дело в том, что в своих адвокатских романах автор частично опирается на реальные события, в которых он принимал участие, в ходе осуществления своей адвокатской деятельности. Согласно ст. 6 Кодекса профессиональной этики адвоката, правила сохранения профессиональной тайны распространяются на факт обращения к адвокату, включая имена и названия доверителей. Ни в одном своем произведении Павел Астахов не упоминает точного имени не только своего доверителя, но и иных, проходящих по делу, лиц. Однако как в этике, так и в праве важным является не столько буква, сколько дух закона. По духу закона от адвоката не должна исходить информация, полученная в ходе осуществления им своей адвокатской деятельности, по которой можно было бы идентифицировать доверителя и определенные события. Автор адвокатских романов так изменяет фамилии главных участников реальных событий, что они легко узнаются, как и сами события.

Bсе это, впрочем, не значит, что адвокат не может публично освещать дело своего клиента. Дело в том, что при расследовании конкретных уголовных дел, СМИ используются следственными органами в целях демонизации образа клиента адвоката. Это осуществляется, например, использованием прокурором на пресс-конференциях по конкретному уголовному делу фразы: «Вор должен сидеть в тюрьме». Нам представляется, что в современном уголовном процессе распространение в средствах массовой информации материалов по делу, которые стали известны адвокату, является одним из методов процессуальной борьбы в ходе расследования и рассмотрения конкретного уголовного дела.

Нельзя не сказать и о другой точке зрения по рассматриваемому аспекту. Так, согласно позиции известного специалиста в области адвокатуры - М.Ю. Барщевского: «Что же касается комментариев по поводу конкретного дела, то, на наш взгляд, нельзя признавать правильным комментарии адвоката по обстоятельствам того дела, которое он ведет, до его разрешения судебными органами» ${ }^{8}$.

В любом случае, что касается ситуации с разглашением адвокатской тайны в адвокатских романах, то это уже никак нельзя оправдать применением особых приемов адвокатской борьбы. Ведь дело уже завершено, и разглашение происходит не в интересах клиента, а в интересах адвоката-писателя.

Изложенные в статье ограничения, налагаемые на адвоката, не являются исчерпывающими. Нами

${ }^{8}$ Барщевский М. Ю. Адвокатская этика. 2-е изд., испр. - М., 200. C. 150 . были изложены только те из них, которые являются на сегодня наиболее актуальными. Однако, при занятии адвокатом любым непрофилирующим видом деятельности, последний должен исходить из тех принципов, которые привели к возникновению института ограничения адвоката в занятии им иными видами деятельности.

\section{Библиография:}

1. Барщевский М. Ю. Адвокатская этика. 2-е изд., испр. - М., 200.

2. Буробин В. Н. Коммерциализация адвокатуры - благо для ее развития // Российская юстиция. N 5. 2002.

3. Кучерена А.Г. Адвокатура: Учебник. - М., 2004.

4. Лохвицкий А.В. Французская адвокатура Профессия адвоката: Сборник работ о французской адвокатуре / Сост. А.В. Поляков. - М., 2006.

5. Мельниченко Р. Г. Поправки к Закону об адвокатуре: работа над ошибками // Адвокат. № 5.2005.

6. Молло Ф. Правила адвокатской профессии во Франции. М., 1894.

7. Обзор дисциплинарной практики Совета Адвокатской палаты г. Москвы // Адвокат. № 6.2008 .

8. Резник. Г. В адвокатуре завелся вирус коммерции, но эпидемия предотвратима // Российская юстиция. N 11. 1999.

9. Смоленский М.Б. Адвокатская деятельность и адвокатура Российской Федерации: Учебник. Ростов н/Д., 2003.

\section{References (transliteration):}

1. Barschevskiy M. Yu. Advokatskaya etika. 2-e izd., ispr. - M., 200.

2. Burobin V. N. Kommercializaciya advokatury blago dlya ee razvitiya // Rossiyskaya yusticiya. N 5. 2002.

3. Kucherena A.G. Advokatura: Uchebnik. - M., 2004.

4. Lohvickiy A.V. Francuzskaya advokatura Professiya advokata: Sbornik rabot o francuzskoy advokature / Sost. A.V. Polyakov. - M., 2006.

5. Mel'nichenko R. G. Popravki k Zakonu ob advokature: rabota nad oshibkami // Advokat. № 5. 2005.

6. Mollo F. Pravila advokatskoy professii vo Francii. M., 1894. 
DOI: $10.7256 / 1811-9018.2013 .7 .988$

При цитировании этой статьи сноска на dоі обязательна

Закон и правопорядок

7. Reznik. G. V advokature zavelsya virus kommercii, no epidemiya predotvratima // Rossiyskaya yusticiya. N 11. 1999.
8. Smolenskiy M.B. Advokatskaya deyatel'nost' i advokatura Rossiyskoy Federacii: Uchebnik. Rostov n/D., 2003. 